\title{
The Submarine Record of a Large-Scale Explosive Eruption in the Vanuatu arc: $\sim 1$ Ma Efaté Pumice Formation
}

\author{
Alison M. Raos \\ Centre for Ore Deposit Research and the School of Earth Sciences, University of Tasmania, Hobart, Australia \\ Present address: Esso Australia Pty Ltd, Melbourne, Australia \\ Jocelyn McPhie
}

Centre for Ore Deposit Research and the School of Earth Sciences, University of Tasmania, Hobart, Australia

The Efaté Pumice Formation (EPF) is the record of a major explosive eruption that occurred in the Vanuatu arc, southwestern Pacific, at about 1 Ma. The EPF is the oldest stratigraphic unit of the Efate Island Group and consists of a succession of non-welded, trachydacitic pumice breccia and shard-rich sand and silt beds with a minimum thickness of $\sim 500 \mathrm{~m}$ and a minimum bulk volume of approximately $85 \mathrm{~km}^{3}$. The lower part (Efaté Pumice Breccias) of the EPF comprises very thick beds composed almost exclusively of glassy, trachydacitic, pumice fragments with ragged terminations. In contrast, the upper part (Rentabau Tuffs) consists of up to $70 \mathrm{~m}$ of well-bedded and well-sorted shard-rich sand and silt. The clast population of this upper part comprises $>95 \%$ glassy or formerly glassy shards, but fossil foraminifera are a ubiquitous and important non-volcanic component. Some glass shards have blocky, equant shapes and arcuate fracture surfaces, features typically associated with the influence of external water during fragmentation, but most are cuspate and platy bubble-wall shards. Pyroclast morphologies indicate that the Efaté Pumice Breccias were largely generated by magmatic-volatile-driven ("dry"), explosive fragmentation processes, and lithofacies characteristics indicate deposition in below-storm-wave-base environments, from eruption-sourced, water-supported density currents of waterlogged pumice. The Rentabau Tuffs are interpreted to represent a change to hydromagmatic activity in response to waning discharge that allowed ingress of water (presumably seawater) to the vent(s).

\section{INTRODUCTION}

High-silica magmas in island arcs may produce highly explosive eruptions in both subaerial and submarine environments. In island arcs in particular, the best-preserved record of such events is likely to be submarine. Submarine deposits from explosive eruptions have been recognised in both modern settings and throughout the rock record [e.g. 
Fiske, 1969; Sparks et al., 1980; Busby-Spera, 1986; Cashman and Fiske, 1990]. Because modern examples are difficult to study, understanding of facies and transport and depositional mechanisms depends largely on ancient examples now well exposed on land [e.g. Soh et al., 1989; Mángano and Buatois, 1997; Stow et al., 1998; Allen and McPhie, 2000].

The non-welded, pumice and shard-rich deposits of the Efaté Pumice Formation in the immature Vanuatu island arc are $>500 \mathrm{~m}$-thick and currently cover $160 \mathrm{~km}^{2}$. These deposits were generated by a large-scale eruption of evolved trachydacite magma and rapidly emplaced in a submarine environment. Textures and depositional structures in the Efate Pumice Formation are very well preserved in scattered cliff outcrops on Efaté and nearby islands. In this paper we describe the Efate Pumice Formation and use the lithofacies and textural characteristics to constrain the eruption and depositional processes and setting.

\section{GEOLOGICAL SETTING}

The Vanuatu arc forms part of a chain of Tertiary to Recent island arcs that mark the boundary between the Pacific plate and the Indo-Australian plate in the southwestern Pacific (inset, Figure 1). Subaerial pyroclastic deposits associated with large-scale, explosive eruptions occur at several caldera centers in the Vanuatu arc [e.g. Robin et al., 1993; Robin et al., 1994a; Robin et al., 1994b; Robin et al., 1995], and other possible calderas probably occur offshore, for example, in the region immediately north of Efaté [Crawford et al., 1988].

The thick pyroclastic sequence on Efate is distinctive in two key ways: (1) the Efaté deposits are exclusively trachydacitic; basaltic and basaltic andesite products dominate at all other centers, and (2) the Efaté pyroclastic sequences were deposited exclusively in submarine environments whereas other exposed modern and recent Vanuatu arc pyro-

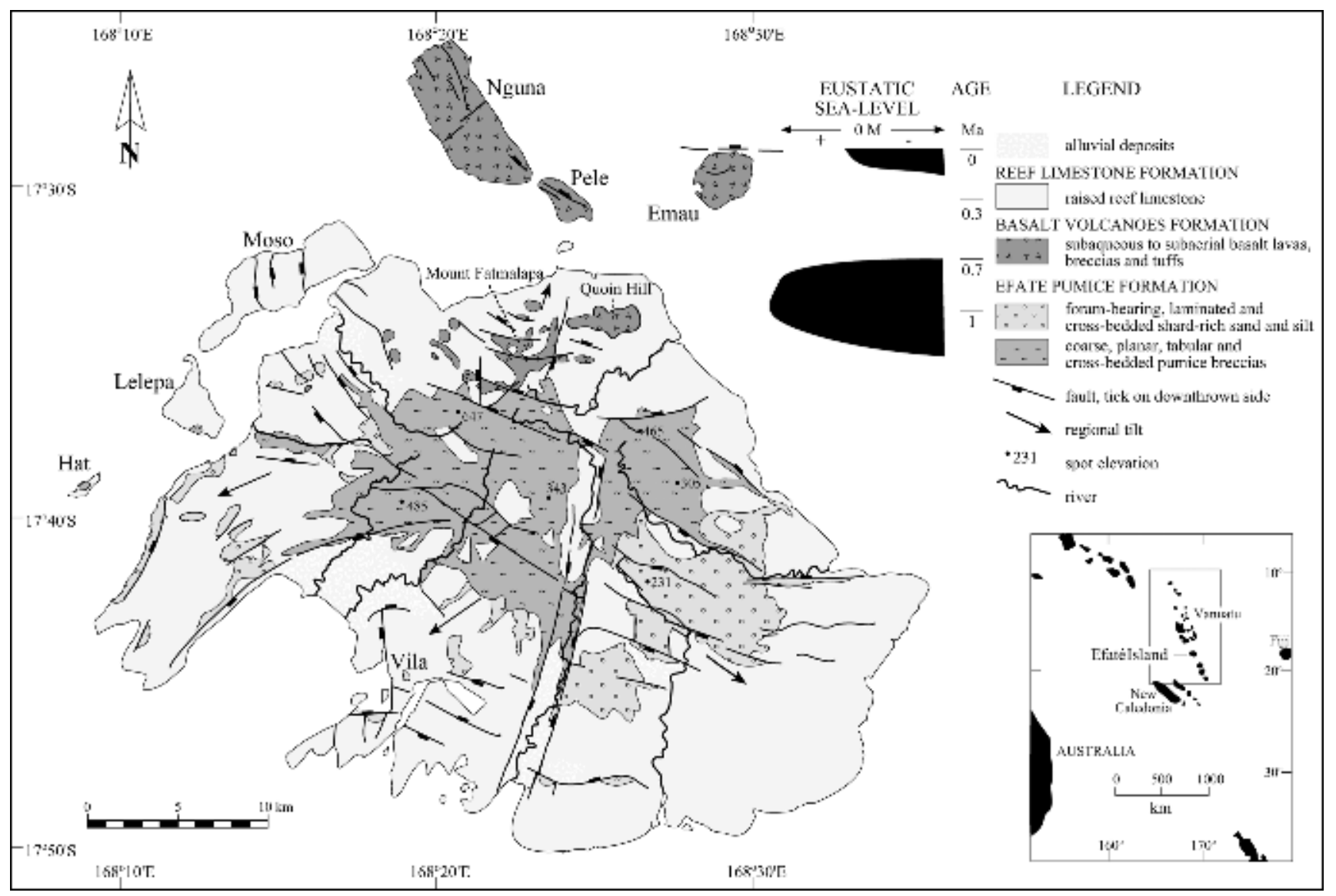

Figure 1. Geology and structure of the Efaté Island Group, Vanauatu arc, southwestern Pacific. Modified from Ash et al. [1978], and incorporating eustatic sea-level curves from Haq et al. [1988]. 
clastic sequences that resulted from large-scale eruptions, were all emplaced subaerially. Interestingly, episodes of hydromagmatic activity have been common in many subaerial explosive eruptions in the active Vanuatu arc [e.g. Robin et al., 1993; Robin et al., 1994b].

\section{THE GEOLOGY OF EFATE}

Efaté consists of two major volcanic formations overlain by reef-forming limestone [Figure 1, Mawson, 1905; Obellianne, 1958; Ash et al., 1978]. The oldest formation on Efaté is the $\sim 1$ Ma Efaté Pumice Formation (EPF) exclusively comprising trachydacitic pumice breccia and shardrich sand and silt facies. The Pleistocene to Recent $(\sim 0.7-0$ Ma) Basalt Volcanoes Formation (BVF) unconformably overlies the EPF and is restricted to the north of Efaté, and islands offshore (Figure 2). Lithofacies include submarine to subaerial basaltic lavas, and associated fine- to coarsegrained volcaniclastic facies. Deposition of in situ biogenic and detrital facies of the Reef Limestone Formation (RLF) began in the late Pleistocene $(\sim 0.3 \mathrm{Ma})$ and this unit unconformably onlaps both the EPF and the BVF. Reef growth is recorded in a series of terraces that developed during broadly domal uplift of Efaté, Hat, Lelepa and Moso islands (Figure 2).

\section{EFATE PUMICE FORMATION}

The EPF is exposed in central Efaté, and on the nearby islands of Lelepa and Hat (Figure 1). Beds are essentially flat-lying and the deposits are only poorly consolidated. The base of the formation is not currently exposed and the upper contact with onlapping RLF is erosional everywhere. The EPF is informally divided into upper (Efaté Pumice Breccias) and lower (Rentabau Tuffs) members that differ in their principal facies characteristics (Table 1). The contact between the upper and lower units is apparently conformable, non-erosive and knife-sharp (Figure 2).

\section{Efaté Pumice Breccias}

The Efaté Pumice Breccias have a minimum stratigraphic thickness of $\sim 350 \mathrm{~m}$ and a minimum bulk volume of $65-80 \mathrm{~km}^{3}$. They are primarily composed of angular to ragged-ended, elongate, tube-pumice clasts (60-80\%) and less abundant round-vesicle pumice clasts (5-20\%), with subordinate $(5-10 \%)$ perlitic obsidian and porphyritic lava clasts in a minor matrix (5-15\%) of non-abraded, Y-shaped, cuspate and platy bubble-wall shards, crystals and crystal fragments (Figure 3a). Pumice clasts have vesicularities,

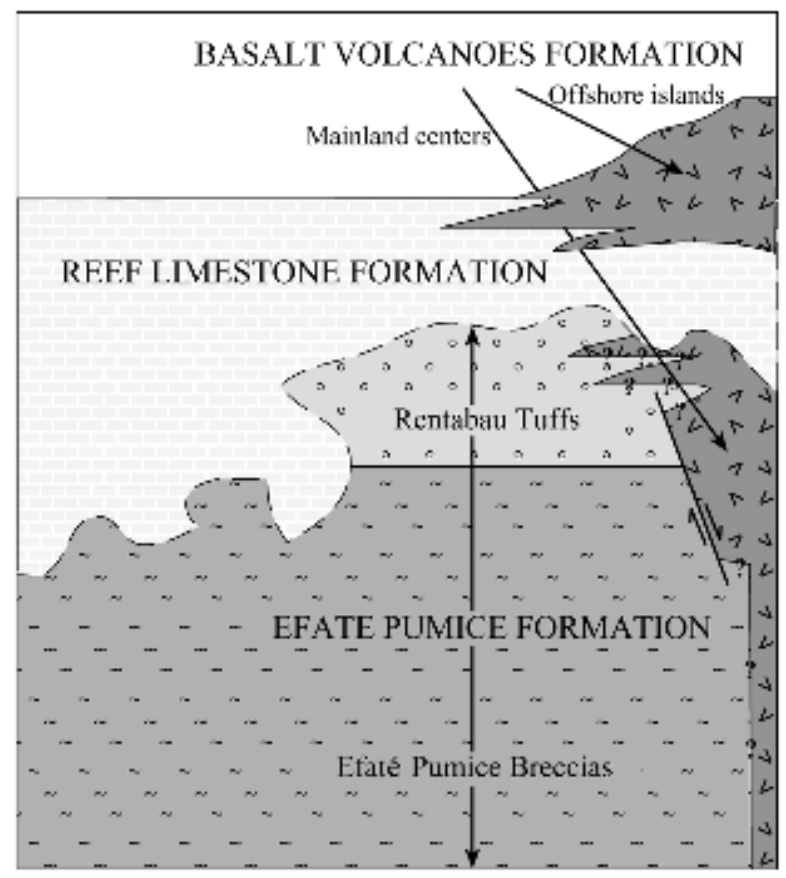

Figure 2. Schematic diagram showing the relationships between the three formations on Efaté Island. Dashed lines represent an unconformable contact, thicker lines are faulted contacts, and ? indicate that these contact relationships are obscured or not exposed.

determined by analysis of oriented thin sections, in the range $65-85 \%$. The glassy components are uniformly trachydacitic and the crystal population comprises plagioclase (andesine), clino- and orthopyroxene, Ti-magnetite and accessory apatite. Rare clasts occurring in lithic-rich intervals include abraded limestone fragments, well-rounded scoria clasts and elongated intraclasts of shard-rich sand and silt.

The Efaté Pumice Breccias comprise a coarse and fine facies association (Table 1). The coarse facies are dominated by planar-tabular, structureless to normally graded and internally stratified, thick to very thick beds (up to $5 \mathrm{~m}$ ) of clast-supported, moderately sorted, $1-6 \mathrm{~cm}$ pumice fragments (MPB, SPB, XPB; Table 1). Pumice breccia beds have sharp bases and gradational to erosional upper contacts (Figure 3b). These beds commonly have an inversely graded crystal-rich basal layer up to $5 \mathrm{~cm}$ thick, and are locally interbedded with well-sorted, shard-rich facies. The fine facies include thin to very thin, tabular, shard-rich sand and silt interbeds with textures varying from structureless to normally graded, to planar- and locally cross-stratified (MAS, SAS, XAS, Table 1, Figure 3c). Shard-rich sand and silt beds have sharp bases and locally display flame struc- 

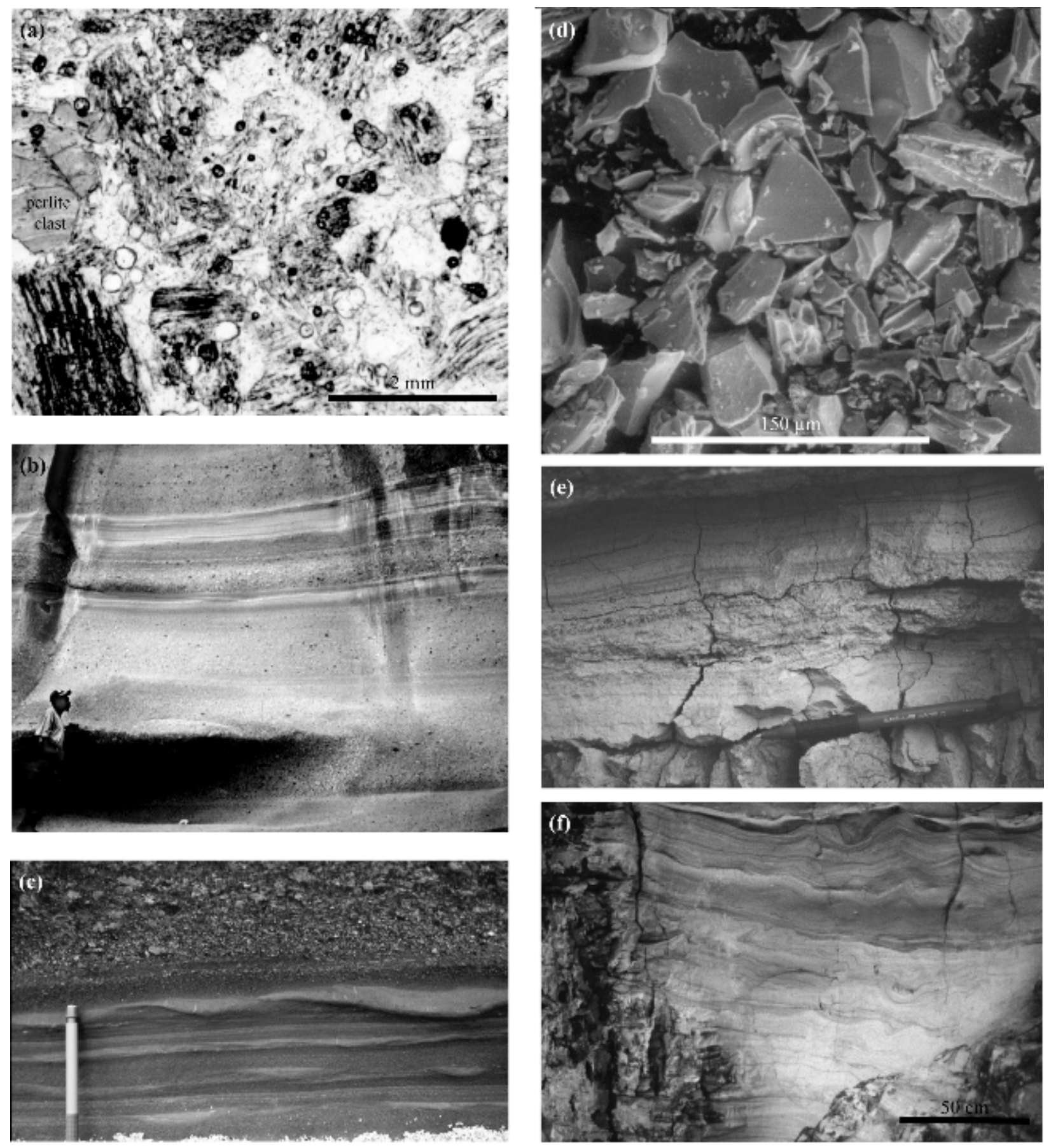

Figure 3. Components and facies of the Efaté Pumice Formation (EPF). (a)-(c) Efaté Pumice Breccias: (a) photomicrograph of clast-supported fabric in pumiceous sand; note the abundance of elongate tube pumice clasts, sample AR064, Lelepa Island. (b) Very thick beds of clast-supported massive pumice breccia with interbeds of shard-rich sand and silt, person for scale, Lelepa Island. (c) Fine-grained interval consisting of fine laminated sand, interbedded with angle-of-repose cross-bedding and massive shard-rich silt lenses and drapes (pencil is $14.5 \mathrm{~cm}$ long, $8 \mathrm{~mm}$ wide), Lelepa Island. (d)-(f) Rentabau Tuffs: (d) scanning electron microscope image of platy shards from a very fine sand, sample AR016, south-central Efaté. (e) Massive (below pencil) and laminated (above pencil) shard-rich sand beds (pencil is $14.5 \mathrm{~cm}$ long, $8 \mathrm{~mm}$ wide), Forari, SE Efaté. (f) Plastically-deformed (convolute) bedding in laminated shard-rich sand, note thin (3 $\mathrm{cm})$ indurated bed of massive very fine grained shard-rich sand, central Efaté. 
Table 1. Summarised facies descriptions for the principal facies of the Efaté Pumice Formation.

\begin{tabular}{ll}
\hline LITHOFACIES & BED THICKNESS \\
\hline $\begin{array}{ll}\text { Efaté Pumice Breccias } \\
\text { massive pumice }\end{array}$ & $\begin{array}{l}0.5-5.0 \mathrm{~m} \text { (thick to } \\
\text { breccia (MPB) }\end{array}$ \\
very thick)
\end{tabular}

stratified pumice

breccia (SPB)

cross-stratified pumice breccia (XPB)

massive shard-rich sand and silt (MAS)

stratified shard-rich sand and gravelly sand (SAS)

cross-stratified shardrich sand and gravelly sand (XAS)

\section{Rentabau Tuffs}

massive shard-rich sand very thin to thick and silt (MAS)

laminated shard-rich sand and silt (SAS)

cross-stratified shardrich sand and silt (XAS)

convolute bedded shard-rich sand and silt (CAS)
0.2-5.0 m (medium to very thick)

$0.5-5.0 \mathrm{~m}$ (thick to very thick)

thin to very thin

thin to very thin

thin to very thin

0.1-1.2 m (medium to very thick)

$0.1-0.5 \mathrm{~m}$ (medium to thick)

0.3-1 $\mathrm{m}$ (medium to thick intervals) GENERAL DESCRIPTION DEPOSITIONAL PROCESSES

clast-supported, moderately sorted, fines-poor, pumice breccia; structureless to normally or inverse graded close to bed contacts; planar, tabular, laterally continuous beds with sharp and erosional, to gradational bases; may have lithicrich basal layer locally

clast-supported, moderately to well sorted, finespoor pumice breccia; planar stratified and locally normally and inversely graded, planar, tabular, laterally continuous beds with sharp bases

clast-supported, moderately sorted, fines-poor, pumice breccia; internally stratified and crossstratified discontinuous beds with sharp generally erosive bases; oversteepened foreset structures and isolated scour and fill structures occur locally

shard-rich, well sorted, structureless silt and fine sand; some planar, tabular beds with sharp bases, commonly forms draping beds and may show injection structures and soft-sediment deformation features at upper contacts; indurated and locally carbonate veined

shard-rich, well sorted gravelly sand to silt; planar, tabular beds with sharp bases; planar stratified and laminated; commonly contain single grain thickness layers; crystal-rich layers common

shard-rich, well sorted gravelly sand to silt; planar, tabular beds with sharp bases; isolated or locally grouped asymmetric ripple bedforms; commonly contain granular pumice stringers or single-grain thickness layers; crystal rich layers common

shard-rich, well sorted sand to silt; planar, tabular, laterally continuous, structureless beds with sharp, conformable contacts; sole marks and load casts occur locally; may contain fossil foraminifera and rare outsize pumice clasts

shard-rich, well sorted sand to silt; planar, tabular internally thickly laminated beds with sharp conformable contacts; may contain rare low-angle truncation surfaces; may contain fossil foraminifera and rare outsize pumice clasts

shard-rich, well sorted sand to silt; planar, tabular laterally continuous or rarely lenticular beds with sharp conformable contacts; bed bases may be undulose; ripple bedforms are typically asymmetric and isolated, but climbing ripples and trough crosslaminae occur locally; may contain fossil foraminifera and rare outsize pumice clasts

shard-rich, well sorted sand to silt; contorted bedding with irregular folds; intervals have discordant sharp bases and tops; may contain fossil foraminifera and rare outsize pumice clasts pumice-rich, water-supported, density currents

traction sedimentation from pumice-rich, water-supported density currents

traction sedimentation from pumice-rich, water-supported density currents

suspension fallout deposition including fallout of the finest particles from shard-rich, watersupported density currents

traction plus suspension sedimentation in shard-rich, water-supported density currents

traction sedimentation in shard-rich, water-supported volcaniclastic density currents

shard-rich, water-supported density currents

traction plus suspension sedimentation in shard-rich, water-supported density currents and bottom currents

traction sedimentation in shardrich, water-supported density currents and bottom currents

soft-sediment slumping 
tures and load casts, and upper contacts are gradational or erosional. Tractional sedimentary structures, including planar and cross-stratification, internal scouring and low-angle bedding truncations occur in both the fine and the coarse facies (Table 1, Figure 4a).

\section{Rentabau Tuffs}

The Rentabau Tuffs occur in sections up to $70 \mathrm{~m}$ thick, and have a minimum bulk volume of $3-5 \mathrm{~km}^{3}$. The

(a)

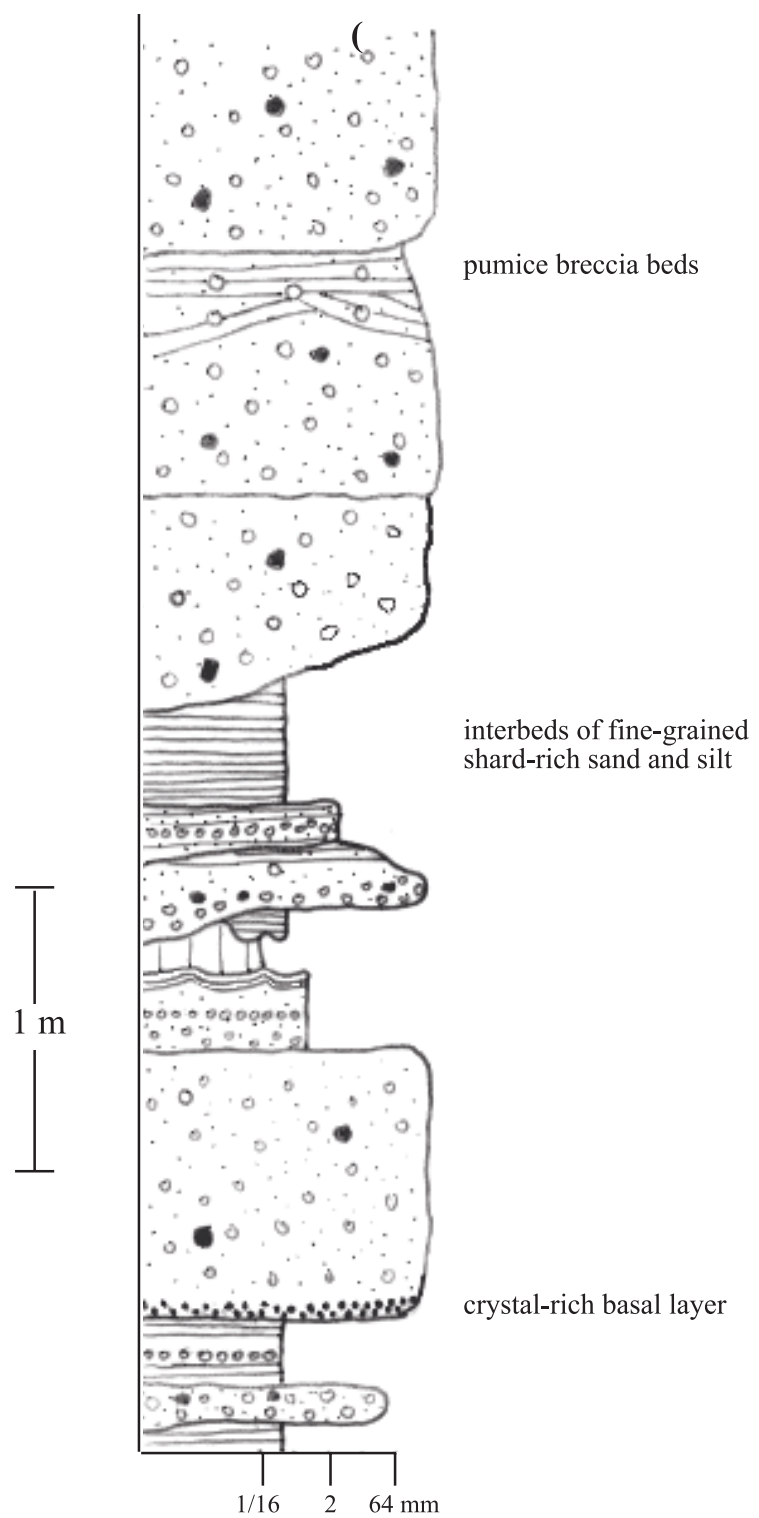

Rentabau Tuffs are compositionally very similar to the Efaté Pumice Breccias, comprising $>90 \%$ tube pumice, bubblewall, cuspate and blocky, glassy (or formerly glassy) shards. Glass shards (where preserved) are chemically identical to glassy components in the underlying Efaté Pumice Breccias and the majority are unabraded. Pumice shards have both ragged and fracture-bounded terminations and blocky shards have curviplanar margins (Figure 3d). Euhedral crystals and angular crystal fragments of plagioclase (andesine), clinoand orthopyroxene, and Ti-magnetite account for up to $10 \%$

b)

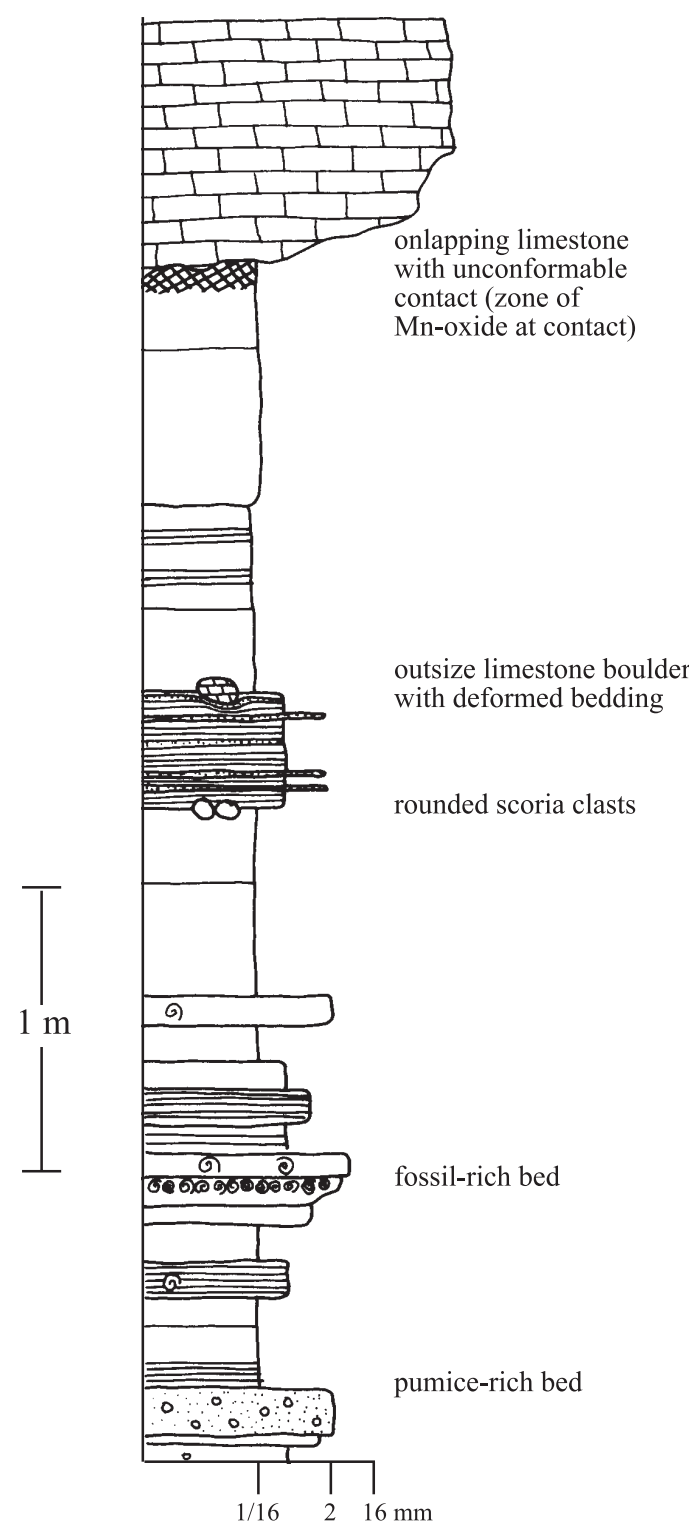

Figure 4. Representative graphic logs from the EPF. (a) Thick to very thick breccia beds and interbedded shard-rich sand and silt from the Efaté Pumice Breccias, Lelepa Island. (b) Shard-rich, fossil bearing sand and silt beds from the Rentabau Tuffs, at Forari, southeastern Efaté. 
of components and are locally concentrated within crystalrich laminae. Non-volcanic clasts include a ubiquitous but minor (3-5 vol.\%) population of marine fossil foraminifera.

Bedding in the Rentabau Tuffs is remarkably uniform (Figure 4b). Thin to medium beds with planar, tabular geometries and sharp, conformable contacts are typical (Figure 3e). Beds are dominantly massive or internally laminated and locally ripple-laminated, and well-sorted (MAS, SAS, XAS, Table 1), although rare, randomly scattered, outsize pumice clasts (up to $3 \mathrm{~cm}$ ) may be present. Intervals of convolute bedding are locally important (CAS, Table 1, Figure 3f). Many sections of the Rentabau Tuffs are substantially altered to halloysite clays.

\section{DISCUSSION}

\section{Fragmentation processes and source of pyroclasts}

The EPF consists almost exclusively of highly vesicular pumice and cuspate, blocky and bubble-wall glass shards and crystals. Such clasts are typically produced by major explosive eruptions of vesiculating magma. The majority of glassy pumice clasts in the Efaté Pumice Breccias have ruptured bubble walls, and are relatively coarse $(1-6 \mathrm{~cm})$, indicating that fragmentation by "dry" magmatic-volatile- driven explosions dominated [Sparks, 1978; Heiken and Wohletz, 1991; Cashman and Mangan, 1994]. Curviplanar surfaces on perlitic obsidian clasts probably represent original macroperlite fracture traces.

In contrast, many of the pumiceous shards in the Rentabau Tuffs have subplanar fracture-bounded surfaces, and some shards have equant, blocky shapes with arcuate clast margins. These features are commonly generated by interaction of magma with external water [Sheridan and Wohletz, 1981; Wohletz, 1983]. In addition, the consistently fine grain size of the Rentabau Tuffs is consistent with hydromagmatic fragmentation mechanisms being important in the generation of these pyroclasts [Self and Sparks, 1978; Wohletz et al., 1989].

\section{Transport and depositional mechanisms}

Deposition of the Efaté Pumice Breccias at $\sim 1$ Ma coincides with a period of high eustatic sea level and a period of rapid volcaniclastic and hemipelagic sedimentation in the central Vanuatu arc [Figure 1, Haq et al., 1998; Goud Collins, 1994]. A marine setting for deposition of the Efaté Pumice Breccias is consistent with these conditions and is supported in part by the presence of marine fossils in the conformably overlying Rentabau Tuffs. In addition, reef limestone unconformably overlies both the Efaté Pumice
Breccias and the Rentabau Tuffs, and there is no evidence for hot emplacement or gas-supported transport in any facies of the Efate Pumice Breccias. Instead, depositional structures, including very thick structureless and stratified, planar, tabular pumice beds, suggest the dominance watersupported volcaniclastic density currents during transport and deposition. The facies characteristics, together with the absence of wave-generated bedforms are consistent with a below-wave-base environment [c.f. Einsele, 1991]. Stratification, cross-stratification and grading developed as particle-rich currents lost capacity, allowing traction sedimentation to dominate over suspension fallout sedimentation [c.f. Hiscott, 1994]. The generally fines-poor nature of the pumice breccias probably reflects efficient elutriation of fine pyroclasts during transport [c.f. Cousineau, 1994; Druitt, 1995]. Elutriated shards and crystals would have created suspensions that eventually generated fine-grained density currents from which the shard-rich interbeds were deposited.

Foraminifera tests are widely distributed but sparse $(<2$ vol.\%) throughout the Rentabau Tuffs and include planktic species typical of deep sea or open water settings [Ash et al., 1978; Raos, 2001]. Hence foraminifera in the Rentabau Tuffs probably settled from suspension, together with shards and crystals. The presence of structureless and laminated beds, and ripple-laminated intervals implies that deposition was dominated by density current and suspension fallout processes [c.f. Lowe, 1982]. The monotonous and extremely regular bedding of the Rentabau Tuffs, and the dominance of fine grain sizes, plus the lack of erosional contacts with the underlying Efate Pumice Breccias, is consistent with a relatively deep, non-channelised setting. The convolute bedded intervals probably resulted from slumping of unconsolidated sediment on the submarine slope. Earthquakes accompanying active volcanism, and high sedimentation rates were probably important mechanisms for triggering sediment slumping in the Rentabau Tuffs [c.f. Niem, 1977; Stow, 1994].

\section{Vent setting}

The Efaté Pumice Formation was clearly deposited in a submarine environment but the vent or vents for the eruption are not preserved or not exposed and their precise location remains unknown. However, sparse palaeocurrent indicators and systematic variations in grain-size point to a source offshore to the north of Efaté [Raos, 2001]. The vent setting is also difficult to constrain. Although clast morphologies in the Efaté Pumice Breccias suggest dominantly "dry" explosive fragmentation, this does not preclude eruption from submarine vents: energetic discharge may prevent water gaining access to vents, and further, submarine eruption columns may remain protected from interaction with seawater by a 
steam carapace [e.g. Kano et al., 1996]. For the Rentabau Tuffs, the overwhelming dominance of glass shards $<2 \mathrm{~mm}$, and the presence of shards bounded by arcuate fracture surfaces, are typical of pyroclasts resulting from hydromagmatic activity. At Efaté the external water may have been the sea, implying that the vent was submerged. In addition, no regional ash layer correlated with the Efaté Pumice Formation has been recognised within the Vanuatu arc. A subaerial eruption of this style and scale would be expected to produce a widespread ash bed [e.g. Schmincke and van den Bogaard, 1991], implying that in this case, vents were probably submarine; although the eruption column may have breached the sea surface without forming a high plume (Figure 5a).

Charred plant remains, terrestrial fossils or accretionary lapilli, which would positively indicate that the eruption occurred from a subaerial vent, are notably absent in beds of the EPF. Such particles are commonly preserved in other submarine successions from subaerial eruptions, even up to $250 \mathrm{~km}$ from source [e.g. Carey and Sigurdsson, 1980; Soh et al., 1989; Stow et al., 1998]. Hence the available evidence favours a submarine eruption for the EPF.

\section{MODEL FOR ERUPTION AND EMPLACEMENT OF THE EFATE PUMICE FORMATION}

\section{Stage I - Efaté Pumice Breccias}

Vesiculating trachydacite magma was explosively ejected from shallow submarine vents located to the north of Efate (Figure 5a). Turbulent mixing with seawater and overload-
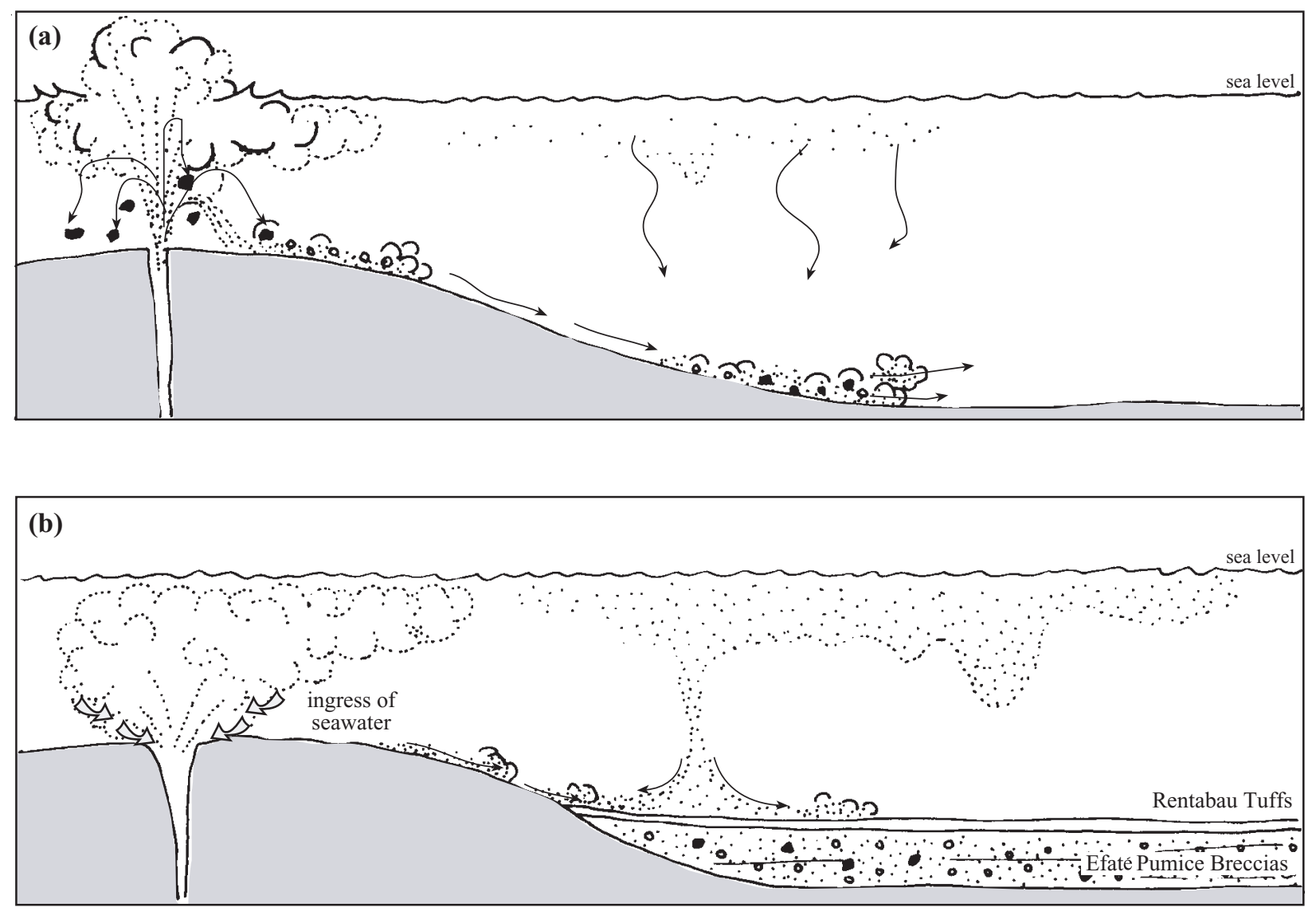

Figure 5. Model for eruption and emplacement of the EPF. (a) Explosive eruption of vesiculating magma from a submerged vent(s) generated abundant highly vesicular pumice clasts and finer glass shards. Turbulent mixing of pyroclasts with seawater generated pumice-rich density currents that deposited thick pumice breccia beds in nearby depocentres. The finest particles were deposited from separate fine-grained, currents produced as by-products of the coarse pumiceous currents, and from suspension settling. As the eruption intensity waned, (b) seawater gained access to the vesiculating magma resulting in hydromagmatic explosions. Abundant fine pyroclasts were incorporated in eruptionsourced shard-rich density currents and descending vertical plumes that rapidly deposited remarkably uniform shardrich sand and silt beds. See text for details. 
ing by pyroclasts led to continuous collapse of the submarine eruption column. This collapsing column and continued explosions initiated a succession of volcaniclastic density currents of waterlogged pumiceous debris (Figure 5a, Fiske and Matsuda, 1964; Cashman and Fiske, 1991]. Hot pumice clasts, in particular the highly permeable tube pumice, rapidly ingested seawater and lost their initial buoyancy to become incorporated in these eruptionsourced, cold (or cool), water-supported, volcaniclastic density currents [e.g. Fiske, 1969; Whitham and Sparks, 1986]. Older lavas and domes were shattered by the explosions generating perlitic obsidian and dense porphyritic lithic blocks that became incorporated into the density currents. The finest particles were segregated from the pumice-rich density currents during current generation, due to their lower densities compared with the waterlogged pumice clasts, and during transport by elutriation [e.g. Cousineau, 1994; Fisher, 1983]. Separate shard-rich currents, generated as by-products of the coarser density currents and from suspension in the water column, locally deposited interbeds of laminated, cross-laminated, and structureless, shard-rich sand and silt. The dominance of mechanically unmodified pyroclasts in the deposits indicates that abrasion following fragmentation was minimal. The Efaté Pumice Breccias may have rapidly accumulated in local depocentres, leading to a very thick and regionally confined succession [e.g. Cousineau, 1994].

\section{Stage II - Rentabau Tuffs}

As the eruption progressed and magma discharge rates were reduced, interaction of the vesiculating magma with seawater led to a change in eruption dynamics. Hydromagmatic explosions occurred (Figure 5b), and generated mainly fine pyroclasts while the magma was still near the point of peak vesiculation [Houghton and Wilson, 1989; Houghton et al, this volume]. Deposition of the pyroclastic debris occurred mainly from cold (or cool) watersupported, density currents generated directly at submarine vents after turbulent mixing of gas-pyroclast dispersions with seawater. Density currents also originated from descending vertical plumes developing in the upper parts of the particle-laden water column [e.g. Carey, 1997; Fiske et al., 1998; Stow et al., 1998]. Probably, seismic activity related to the volcanic eruption, caused local slumping and the development of convolute-bedded intervals within the Rentabau Tuffs. Such seismic events may have triggered further volcaniclastic density currents by remobilisation of this unconsolidated sediment [Niem, 1977; Stow, 1994]. This unit comprises $\sim 98 \%$ pyroclasts and lacks any significant interbeds of hemipelagic sediment, indicating that deposition occurred contemporaneously with explosions, or rapidly following the eruption.

\section{CONCLUSIONS}

The pumice and shard-rich deposits of the EPF were generated by cold (or cool), water-supported, volcaniclastic density currents that were directly fed from contemporaneous, (shallow) submarine, explosive eruption(s). Magmaticvolatile-driven explosive fragmentation processes and energetic discharge dominated in the early phases of the eruption, producing the Efaté Pumice Breccias. As the eruption waned, magma interaction with seawater caused a change to hydromagmatic fragmentation mechanisms. The finegrained pyroclastic debris generated in these explosions was also deposited principally by eruption-sourced, water-supported, volcaniclastic density currents, forming the Rentabau Tuffs. Rapid emplacement and volcanic seismicity following deposition initiated slumping in the poorly consolidated pumiceous sediments.

Acknowledgments. This research was funded in part by an Australian Research Council Large Grant awarded to Professor Tony Crawford for studies in the Vanuatu arc and by the Australian Research Council Special Research Centres program. AMR acknowledges a School of Science and Technology scholarship from the University of Tasmania that enabled her $\mathrm{PhD}$ research on Efaté Island.

\section{REFERENCES}

Allen, S.R., and J. McPhie, Water-settling and resedimentation of submarine rhyolitic pumice at Yali, eastern Aegean, Greece, Journal of Volcanology and Geothermal Research, 95, 285-307, 2000.

Ash, R.P., J.N. Carney, and A. Macfarlane, Geology of Efaté and Offshore Islands, pp. 49, New Hebrides Condominium Geological Survey, 1978.

Busby-Spera, C.J., Depositional features of rhyolitic and andesitic volcaniclastic rocks of the Mineral King submarine caldera complex, Sierra Nevada, California, Journal of Volcanology and Geothermal Research, 27, 43-76, 1986.

Carey, S., Influence of convective sedimentation on the formation of widespread tephra fall layers in the deep sea, Geology, 25 (9), 839-842, 1997.

Carey, S.N., and H. Sigurdsson, The Roseau Ash: deep-sea tephra deposits from a major eruption on Domenica, Lesser Antilles Arc, Journal of Volcanology and Geothermal Research, 7, 67-86, 1980.

Cashman, K.V., and R.S. Fiske, Fallout of pyroclastic debris from submarine volcanic eruptions, Science, 253, 275-280, 1991.

Cashman, K.V., M.T. Mangan, and S. Newman, Surface degassing and modifications to vesicle size distributions in active basalt 
flows, Journal of Volcanology and Geothermal Research, 61, 45-68, 1994.

Cousineau, P.A., Subaqueous pyroclastic deposits in an Ordovician fore-arc basin: an example from the Saint-Victor Formation, Quebec Appalachians, Canada, Journal of Sedimentary Research, A64, 867-880, 1994.

Crawford, A.J., H.G. Greene, and N.F. Exon, Geology, petrology and geochemistry of submarine volcanoes around Epi Island, New Hebrides Island Arc, in Geology and Offshore Resources of Pacific Island Arcs - Vanuatu Region, edited by H.G. Greene, and F.L. Wong, pp. 301-327, Circum-Pacific Council for Energy and Mineral Resources, Huston, Texas, 1988.

Einsele, G., Submarine mass flow deposits and turbidites, in Cycles and Events in Stratigraphy, edited by G. Einsele, W. Ricken, and A. Seilacher, pp. 313-339, Springer-Verlag, Berlin, Heidelberg, 1991.

Fisher, R.V., Flow transformations in sediment gravity flows, Geology, 11, 273-274, 1983.

Fiske, R.S., Recognition of pumice in marine pyroclastic rocks, Geological Society of America Bulletin, 80, 1-8, 1969.

Fiske, R.S., K.V. Cashman, A. Shibata, and K. Watanabe, Tephra dispersal from Myojinsho, Japan, during its shallow submarine eruption of 1952-53, Bulletin of Volcanology, 59, 263-275, 1998.

Fiske, R.S., and T. Matsuda, Submarine equivalents of ash flows in the Tokiwa Formation, Japan, American Journal of Science, 262, 76-106, 1964

Goud Collins, M.R., Volcaniclastic sediments of the North Aoba Basin: depositional processes and geologic history, in Proceedings of the Ocean Drilling Program, Scientific Results, Leg 134, edited by H.G. Green, J.-Y. Collot, L.B. Stokking, et al. pp. 97-107, ODP, College Station, TX, 1994.

Haq, B.U., J. Hardenbol and P.R. Vail, Mesozoic and Cenozoic chronostratigraphy and eustatic cycles, in Sea-level Changes: an integrated approach, edited by C.K. Wilgus, B.S. Hastings, H. Postmentier, et al, pp. 71-108, SEPM Special Publication No. 42, 1988 .

Heiken, G., and K. Wohletz, Fragmentation processes in explosive volcanic eruptions, in Sedimentation in Volcanic Settings, edited by R.V. Fisher, and G.A. Smith, pp. 19-26, SEPM Special Publication No. 45, 1991.

Hiscott, R.N., Loss of capacity, not competence, as the fundamental process governing deposition from turbidity currents, Journal of Sedimentary Research, A64 (2), 209-214, 1994.

Houghton, B.F., and C.J.N. Wilson, A vesicularity index for pyroclastic deposits, Bulletin of Volcanology, 51, 451-462, 1989.

Kano, K., T. Yamamoto, and K. Ono, Subaqueous eruption and emplacement of the Shinjima Pumice, Shinjima (Moeshima) Island, Kagoshima Bay, SW Japan, Journal of Volcanology and Geothermal Research, 71, 187-206, 1996.

Lowe, D.R., Sediment gravity flows: II. Depositional models with special reference to the deposits of high-density turbidity currents, Journal of Sedimentary Petrology, 52 (1), 279-297, 1982.

Mángano, M.G., and L.A. Buatois, Slope-apron deposition in an Ordovician arc-related setting: the Vuelta de Las Tolas Member
(Suri Formation), Famatina Basin, northwest Argentina, Sedimentary Geology, 109, 155-180, 1997.

Mawson, D., The geology of the New Hebrides, Proceedings of the Linnean Society of NSW, 30, 400-485, 1905.

Niem, A.R., Mississippian pyroclastic flow and ash-fall deposits in the deep-marine Ouachita flysch basin, Oklahoma and Arkansas, Geological Society of America Bulletin, 88, 49-61, 1977.

Obellianne, J.-M., Contribution à la connaissance geologique de l'archipel des Nouvelles-Hébrides (îles Vaté, Pentecote, Maewo, Santo)., 76 pp., Foundation Scientifique de la Geologie et de ses Applications, Nancy, 1958.

Raos, A.M., The volcanic and geochemical evolution of a trachydacite-dominated island arc centre: Efaté Island Group, Vanuatu arc, SW Pacific, Unpublished thesis, University of Tasmania, Hobart, 2001.

Robin, C., J.-P. Eissen, and M. Monzier, Ignimbrites of basaltic andesite and andesite compositions from Tanna, New Hebrides Arc, Bulletin of Volcanology, 56, 10-22, 1994a.

Robin, C., J.-P. Eissen, and M. Monzier, Mafic pyroclastic flows at Santa Maria (Gaua) Volcano, Vanuatu: the caldera formation problem in mainly mafic island arc volcanoes, Terra Nova, 7 , 436-443, 1995.

Robin, C., M. Monzier, A.J. Crawford, and S.M. Eggins, The geology, volcanology, petrology-geochemistry and tectonic evolution of the New Hebrides Island Arc, Vanuatu, 86 pp., IAVCEI Pre-conference Excursion Guide A5, 1993.

Robin, C., M. Monzier, and J.-P. Eissen, Formation of the mid-fifteenth century Kuwae caldera (Vanuatu) by an initial hydroclastic and subsequent ignimbritic eruption, Bulletin of Volcanology, 56, 170-183, 1994b.

Schmincke, H.-U., and P. van den Bogaard, Tephra layers and tephra events, in Cycles and Events in Stratigraphy, edited by G. Einsele, W. Ricken, and A. Seilacher, pp. 393-429, SpringerVerlag, Berlin, 1991.

Self, S., and R.S.J. Sparks, Characteristics of widespread pyroclastic deposits formed by the interaction of silicic magma and water, Bulletin of Volcanology, 41 (3), 196-212, 1978.

Sheridan, M.F., and K.H. Wohletz, Hydrovolcanic explosions: the systematics of water-pyroclast equilibration, Science, 212, 1387-1389, 1981.

Soh, W., A. Taira, Y. Ogawa, H. Taniguchi, K.T. Pickering, and D.A.V. Stow, Submarine depositional processes for volcaniclastic sediments in the Mio-Pliocene Misaki Formation, Miura Group, central Japan, in Sedimentary Facies in the Active Plate Margin, edited by A. Taira, and F. Masuda, pp. 619-630, Terra Scientific Publishing Company (TERRAPUB), Tokyo, 1989.

Sparks, R.S.J., The dynamics of bubble formation and growth in magmas: a review and analysis, Journal of Volcanology and Geothermal Research, 3, 1-37, 1978.

Sparks, R.S.J., H. Sigurdsson, and S.N. Carey, The entrance of pyroclastic flows into the sea, II. Theoretical considerations on subaqueous emplacemant and welding, Journal of Volcanology and Geothermal Research, 7, 97-105, 1980. 
Stow, D.A.V., Deep sea processes of sediment transport and deposition, in Sediment transport and depositional processes, edited by K. Pye, pp. 257-291, Blackwell Scientific Publications, Oxford, 1994.

Whitham, A., and R.S.J. Sparks, Pumice, Bulletin of Volcanology, 48, 209-223, 1986.

Wohletz, K.H., Mechanisms of hydrovolcanic pyroclast formation: grain-size, scanning electron microscopy, and experimental studies, Journal of Volcanology and Geothermal Research, 17, 31-63, 1983.
Wohletz, K.H., M.F. Sheridan, and W.K. Brown, Particle size distributions and the sequential fragmentation/transport theory applied to volcanic ash, Journal of Geophysical Research, 94 (B11), 15,703-15,721, 1989.

J- McPhie. Centre for Ore Deposit Research and the School of Earth Sciences, University of Tasmania, Private Bag 79, Hobart TAS Australia 7001

A.M. Raos. Esso Australia Pty Ltd, 12 Riverside Quay, Southbank VIC Australia 3006 
LOW RES

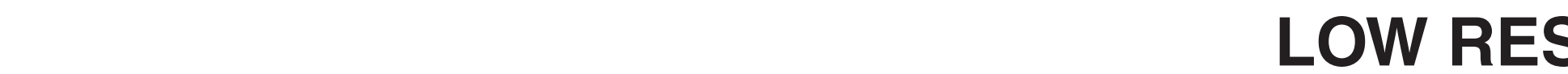

